Arq. Bras. Med. Vet. Zootec., v.70, n.2, p.637-640, 2018

\title{
Comunicação
}

[Communication]

\section{Infeç̧ão sistêmica por Salmonella Typhimurium em papagaio-verdadeiro (Amazona aestiva)}

[Systemic Infection by Salmonella Typhimurium in Blue-fronted

Amazon Parrot (Amazona aestiva)]

\author{
M.L. Souza ${ }^{1,2}$, L.B.S. Azuaga ${ }^{3}$, C.R.M. Coutinho Netto ${ }^{3}$, D.C. Gomes ${ }^{4}$,
} C.A.N. Ramos ${ }^{4}$, C.R.B. Leal $^{4}$

\footnotetext{
${ }^{1}$ Programa de Residência - Faculdade de Medicina Veterinária e Zootecnia - Universidade Federal de Mato Grosso do Sul - Campo Grande, MS

${ }^{2}$ Aluna de pós-graduação - Faculdade de Medicina Veterinária e Zootecnia - Universidade Federal de Mato Grosso do Sul - Campo Grande, MS

${ }^{3}$ Centro de Reabilitação de Animais Silvestres - PMCG - Campo Grande, MS

${ }^{4}$ Faculdade de Medicina Veterinária e Zootecnia - Universidade Federal de Mato Grosso do Sul - Campo Grande, MS
}

A manutenção de animais silvestres em cativeiro domiciliar é uma pratica comum no Brasil. Os papagaios são os preferidos, por serem considerados curiosos, inteligentes e divertidos, serem excelentes imitadores e faladores. Entretanto, podem ser fonte de infecção de algumas zoonoses (Bonello, 2006). O comércio clandestino de animais silvestres é classificado como a terceira maior atividade ilícita do mundo, perdendo apenas para o tráfico de drogas e de armas.

Animais recolhidos em apreensões muitas vezes se encontram em condições inadequadas e com o estado geral de saúde comprometido, sendo, portanto, suscetíveis às diversas infecções e doenças sistêmicas (Carciofi e Saad, 2001). Quando não há condições de serem reintroduzidos na natureza, terminam a vida em zoológicos, ou são enviados aos centros de reabilitação (Vanstreels et al., 2010).

Salmonella Typhimurium é um dos 1.547 sorotipos pertencentes ao grupo da Salmonella enterica subsp. enterica, sendo os sorotipos Typhimurium e Enteritidis encontrados em aves. Esses sorotipos são os de principal importância para a saúde pública. A Salmonella é causadora de toxinfecções alimentares em seres humanos, e, em um estudo realizado em 2010 por Majowicz et al. (2010), estima-se a ocorrência de aproximadamente 93,8 milhões de casos humanos relacionados à Salmonella anualmente em todo o mundo. $S$. Enteritidis e $S$. Typhimurium são sorotipos invasivos, que podem contaminar vários órgãos e causar infecções septicêmicas.

O objetivo deste trabalho foi relatar a mortalidade de papagaios-verdadeiros, mantidos em cativeiro, por Salmonella Typhimurium.

As aves relatadas neste estudo são popularmente chamadas de papagaios-verdadeiros e pertencem à ordem Psittaciformes, família Psittacidae, espécie Amazona aestiva. São aves nativas do Brasil e distribuem-se pelo interior da América do Sul, entre Bolívia, Paraguai e Argentina.

As aves foram apreendidas ainda filhotes em Itaquiraí-MS e Ivinhema-MS, em outubro de 2015, e encaminhadas ao Centro de Reabilitação de Animais silvestres (CRAS) em Campo Grande - Mato Grosso do Sul. Muitas morreram no transporte e durante a estadia no CRAS. Aquelas que sobreviveram foram mantidas em quarentena e depois introduzidas em um recinto de voo com $60 \mathrm{~m}^{2}$ de área total, contendo cerca de 250 papagaios. Em fevereiro de 2016, quando os papagaios possuíam uma idade estimada de seis meses, começaram a apresentar sinais clínicos, como letargia, polidipsia, diarreia, desidratação, conjuntivite, alterações respiratórias, e começaram a vir a óbito 
subitamente. Algumas aves foram encaminhadas ao Hospital Veterinário (HV) da Faculdade de Medicina Veterinária e Zootecnia (FAMEZ) da Universidade Federal de Mato Grosso do Sul (UFMS).

No setor de anatomia patológica do HV, 17 aves foram necropsiadas e pôde-se observar que apresentavam escore corporal regular e mediam cerca de $25 \mathrm{~cm}$, quando o valor normal para a espécie a partir dos quatro meses de idade é de cerca de $35 \mathrm{~cm}$. As penas da cauda estavam sujas de fezes e a plumagem, em geral, apresentava falhas. No sistema cardiovascular, observou-se conteúdo amarelado e gelatinoso no saco pericárdico, além de numerosas petéquias. No sistema respiratório, observou-se hemorragia focal em saco aéreo torácico. No sistema hematopoiético, o baço estava levemente aumentado de tamanho, possuindo pontos amarelados multifocais nas superfícies natural e de corte. O fígado estava moderadamente aumentado de tamanho, com pontos multifocais amarelados por todo o órgão. Ao exame histopatológico do fígado, do baço e dos pulmões, havia agregados bacterianos distribuídos pelos órgãos. $\mathrm{Na}$ mucosa do intestino delgado, havia quantidade moderada de plasmócitos e linfócitos, caracterizando uma enterite linfoplasmocítica.

Devido ao tempo decorrido após o óbito dos animais, não foi possível realizar exames bacteriológicos de todas as aves inicialmente necropsiadas. Dessa forma, fragmentos de fígado e baço de três animais foram encaminhados ao Laboratório de Bacteriologia do HV para cultura bacteriana. As amostras foram inicialmente semeadas em ágar infusão de cérebro e coração (BHI). Vinte e quatro horas após a semeadura, observou-se o crescimento de colônias cremosas, circulares, de tamanho pequeno e brilhosas. Deuse início a identificação bacteriana com base nas características morfotintoriais pela coloração de Gram. A confirmação foi realizada de acordo com as características bioquímicas em meios específicos. Os resultados das provas bioquímicas indicaram que se tratava de uma bactéria fermentadora de glicose, não fermentadora de lactose, produtora de gás e de $\mathrm{H}_{2} \mathrm{~S}$, móvel, com indol negativo e citrato positivo. Essas características são compatíveis com o gênero Salmonella spp.
A confirmação do gênero foi realizada por soroaglutinação em lâmina, utilizando-se soro Salmonella polivalente (Probac do Brasilß).

Para confirmação definitiva dos resultados encontrados, as amostras provenientes do isolamento microbiológico foram encaminhadas ao Laboratório de Biologia Molecular do HV para realização da reação em cadeia da polimerase (PCR). Para tanto, DNA foi obtido por termólise, e PCR para o gene fliC (flagelin gene) foi realizada com os primers FlicF (5'CCTGTCGCTGTTGACCCAGA-3') e FlicR (5'-GAGAGGACGTTTTGCGGAACC-3'). Os primers foram desenhados com o auxílio do programa Primer-Blast (Ye et al., 2012). As reações de PCR foram realizadas com um volume final de $25 \mu \mathrm{L}$ contendo $2.5 \mathrm{ul}$ de PCR $10 x$ buffer $(20 \mathrm{mM}$ de Tris-HCl pH 8.3, $50 \mathrm{mM}$ de $\mathrm{KCl}), \quad 1.5 \mathrm{mM}$ de $\mathrm{MgCl}, 0,2 \mathrm{mM}$ de cada deoxynucleosideo triphosphatado, 10pmol de cada primer, $1.5 \mathrm{U}$ de Taq DNA polimerase e aproximadamente 100ng de DNA genômico. A termociclagem foi realizada como descrito a seguir: desnaturação inicial a $95^{\circ} \mathrm{C}$ por três minutos, 30 ciclos consistindo de desnaturação a $95^{\circ} \mathrm{C}$ por $1: 30 \mathrm{~min}$, anelamento a $57^{\circ} \mathrm{C}$ por $30 \mathrm{seg}$ e extensão a $72^{\circ} \mathrm{C}$ por $1: 30 \mathrm{~min}$, seguidos por uma extensão final a $72^{\circ} \mathrm{C}$ por dois minutos. $\mathrm{O}$ produto da PCR foi analisado em gel de agarose a $1 \%$ e sequenciado em ambas as direções pelo método de Sanger em sequenciador automático ABI 3130 (Applied Biosystems). Os cromatogramas foram avaliados e editados com o auxílio do programa BioEdit v.7.2.5 (Hall et al., 1999), e as sequências consenso foram submetidas ao programa BLASTn (Altschul et al., 1990) para determinar a identidade por comparação com sequências de DNA depositadas no GenBank - NCBI. Identidade de $98 \%$ foi observada com sequências de Salmonella Typhimurium. A sequência foi depositada no Genbank.

Segundo Friend e Franson (1999), a transmissão de Salmonella ocorre principalmente pela via fecal-oral, pelo contato direto entre animais infectados e pela ingestão de água e de alimentos contaminados. Os fatores desencadeantes para o surgimento da doença são: estresse, imunossupressão, dose infectante com a qual o animal entrou em contato, via de transmissão, espécie e idade dos acometidos, se o animal 
apresenta alguma doença concomitante e o sorotipo de Salmonella spp. envolvido.

Os sinais clínicos para salmonelose são inespecíficos, mas, em sua maioria, é possível observar a presença de aves com sonolência, tendência das aves amontoarem-se junto à fonte de calor, anorexia severa, aumento do consumo de água, retardo no crescimento, falhas no empenamento, desidratação, enterocolite aguda com diarreia, emplastamento das penas ao redor da cloaca, cegueira, conjuntivite e morte súbita (Back, 2010). Muitos dos sinais relatados por Back (2010) foram encontrados nas aves analisadas, que tinham tamanho inferior ao ideal para a espécie e a idade, cerca de $10 \mathrm{~cm}$ a menos, falhas no empenamento, e apresentavam sinais clínicos de letargia, polidipsia, diarreia, desidratação, conjuntivite e alterações respiratórias, reforçando a confirmação de que o quadro clínico consistia em salmonelose.

Karesh et al. (1997) mostraram, por meio de testes sorológicos, que pássaros de cativeiro eram soropositivos para Salmonella Pullorum, enquanto os de vida livre foram negativos, demonstrando a facilidade da disseminação de patógenos entre os animais quando esses estão aglomerados em recintos. Esses animais se alimentam e defecam em grande densidade no mesmo recinto, o que aumenta a probabilidade de uma contaminação fecal-oral de Salmonella e outros patógenos.

Para a prevenção e o controle da disseminação de patógenos em aves de cativeiro, boas condutas de higiene devem ser tomadas. A desinfecção do ambiente deve ser periódica e o recinto deve ter boa ventilação. $\mathrm{O}$ controle populacional dentro do recinto também deve ser monitorado. Deve-se reduzir o estresse ambiental e de manipulação, e os animais devem ser mantidos com uma ótima nutrição (Marietto-Gonçalves et al., 2010).

Carciofi e Saad (2001) atentam para a questão do manejo nutricional, afirmando que as aves subnutridas têm a capacidade imunológica reduzida e são mais suscetíveis a infecções e doenças sistêmicas, além de terem a capacidade reprodutiva reduzida. As enfermidades de aves em cativeiro, no Brasil, estão frequentemente associadas com manejo inadequado, envolvendo aspectos nutricionais, comportamentais e instalações.
Refsum et al. (2002) realizaram um estudo retrospectivo no período de 1969 a 2000, na Noruega, analisando registros de 470 pássaros de vida livre laboratorialmente confirmados para Salmonella, e em $100 \%$ dos animais avaliados o sorotipo encontrado foi Salmonella Typhimurium, sendo o mesmo sorotipo encontrado em humanos, em outros trabalhos, no mesmo período. Acredita-se que a presença das aves pode ser um fator desencadeante para a transmissão dos patógenos das aves para os humanos.

No estudo de Bonello (2006) para avaliar o manejo e o potencial zoonótico de papagaiosverdadeiros mantidos em cativeiro domiciliar, foi constatado que a maioria das pessoas mantém as aves, mas não tem conhecimento básico de suas necessidades e hábitos de vida, criando-as como pets, com manejo nutricional e sanitário inadequados. Esses proprietários têm um estreito contato com as aves e desconhecem as possíveis enfermidades que elas podem transmitir. Dessa forma, é possível avaliar que, assim, a criação de animais silvestres pode constituir um problema de saúde pública.

A melhor forma de evitar a infecção tanto de animais quanto de humanos por Salmonella é por meio da prevenção, portanto devem-se manter as aves em quarentena para observar alguma manifestação clínica de enfermidades, evitar que elas passem por estresse, diminuir a quantidade de animais que vivem em um mesmo recinto, dar uma boa alimentação e ter cuidados com higiene, limpando e desinfetando frequentemente gaiolas, recintos, bebedouros e comedouros. Ter sempre o acompanhamento veterinário e, se possível, reintroduzi-las à natureza o mais rápido possível. Os humanos também devem prevenir-se lavando mãos e braços após manusear a ave e fazer a limpeza de gaiolas, não deixar a ave próxima de locais onde os humanos alimentam-se e consumir alimentos devidamente inspecionados.

Este trabalho pôde demonstrar a importância e os impactos de encontrar Salmonella spp. em recintos onde muitos animais dividem o mesmo espaço, como CRAS, CETAS, zoológicos e criações, onde os animais ficam mais suscetíveis a infecções e onde há facilidade de disseminação de patógenos entre eles.

Palavras-chave: PCR, Psittaciformes, salmonelose 


\begin{abstract}
The maintenance of wild animals in captivity can be a source for transmission of infectious and zoonotic diseases. In February 2016, blue-fronted amazon parrots that were kept at the Centro de Reabilitação de Animais Silvestres (CRAS) of Campo Grande - MS died suddenly. The specimens were sent to the Universidade Federal de Mato Grosso do Sul (UFMS), Faculdade de Medicina Veterinária e Zootecnia (FAMEZ) to be necropsied. Anatomopathological exams were performed and organ fragments from all systems were collected for histopathological exams. Liver and spleen fragments were also collected for bacteriological exams. Histopathological exam revealed bacterial aggregates distributed through the organs. Bacteriological exam isolated Salmonella spp. from the fragments of liver and spleen. The confirmation of the genus was made by serum agglutination on slide and by the polymerase chain reaction (PCR). The genetic sequencing identified the sample as Salmonella Typhimurium.
\end{abstract}

Keywords: PCR, psittaciformes, salmonellosis

\section{REFERÊNCIAS}

ALTSCHUL, S.F.; GISH, W.; MILLER, W. et al. Basic local alignment search tool. J. Mol. Biol., v.215, p.403-410, 1990.

BACK, A. Manual de doenças de aves. 2.ed. Cascavel, PR: Integração, 2010. 311p.

BONELlo, F.L. Avaliação do manejo e do potencial zoonótico de papagaios-verdadeiros (Amazona aestiva) mantidos em cativeiro domiciliar. 2006. 72f. Dissertação (Mestrado em Ciência Animal) - Faculdade de Odontologia e Curso de Medicina Veterinária da Universidade Estadual Paulista, SP.

CARCIOFI, A.C.; SAAD, C.E.P. Nutrition and nutritional problems in wild animal. In: FOWLER, M.E.; CUBAS, Z.S (Eds.). Biology, medicine, and surgery of South American wild animals. Ames, IA: Iowa State University Press, 2001. p.425-434.

FRIEND, M.; FRANSON, J.C. Field manual of wildlife diseases, general field procedures and diseases of birds. Washington: USGS, 1999. $426 \mathrm{p}$.

HALL, R.E.; KESTLER, D.P.; AGARWAL, S.; GOLDSTEIN, K.M. Expression of the monocytic differentiation/activation factor P48 in Mycoplasma species. Microb. Pathog. v.27, p.145-153, 1999.
KARESH, W.B.; CAMPO A.D.; BRASELTON, W.E.; PUCHE, H. et al. Helth evaluation of freeranging and hand-reared macaws (Ara spp.) in Peru. J. Zoo Wildl Med. v.28, p.368-377, 1997.

MAJOWICZ, S.E.; MUSTO, J.; SCALLAN, E. et al. The global burden of nontyphoidal Salmonella gastroenteritis. Clin. Infect. Dis., v.50, p.882-889, 2010.

MARIETTO-GONÇALVES, G.A.; ALMEIDA, S.M.; LIMA, E.T.; ANDREATTI FILHO, R.L. Detecção de Escherichia coli e Salmonellaspp. em microbiota intestinal de Psittaciformes em fase de reabilitação para soltura. Braz. J. Vet. Res. Anim. Sci. v.47, p.185-189, 2010.

REFSUM, T.; HANDELAND, K.; BAGGESEN, D.L.; HOLSTAD, G. et al. Salmonellae in avian wildlife in Norway from 1969 to 2000 . Am. Soc. Microbiol. v.68, p.5595-5599, 2002.

VANSTREELS, R.E.T.; TEIXEIRA, R.H.F.; CAMARGO, L.C.; NUNES, A.L.V. et al. Impacts of animal traffic on the brazilian amazon parrots (Amazona species) collection of the Quinzinho de Barros Municipal Zoological Park, Brazil, 1986-2007. Zoo Biol. v.29, p.600-614, 2010.

YE, J.; COULOURIS, G.; ZARETSKAYA, I. et al. Primer-BLAST: a tool to design targetspecific primers for polymerase chain reaction. BMC Bioinf., v.13, p.134, 2012. 